\title{
Hallux varus-preaxial polysyndactyly syndrome
}

INSERM

\section{Source}

INSERM. (1999). Orphanet: an online rare disease and orphan drug data base. Hallux varus-preaxial polysyndactyly syndrome. ORPHA:2110

Hallux varus-preaxial polysyndactyly syndrome is a rare, genetic, congenital limb malformation disorder characterized by bilateral medial displacement of the hallux and preaxial polysyndactyly of the first toes. Radiographs show broad, shortened, misshapen first metatarsals and may associate incomplete or complete duplication of proximal phalanges and duplication or triplication of distal phalanges. There have been no further descriptions in the literature since 1980. 